Висновки. Проаналізувавши роботу Державної казначейської служби України слід зазначити, що робота в цілому налагоджена, але $\epsilon$ ряд недоліків які заважають своєчасно і без затримок виконувати ти чи інші питання. Таким чином вирішивши ряд вище перерахованих проблем призведе до більш ефективної роботи Державного казначейства.

\section{СПИСОК ЛІТЕРАТУРИ}

1. Бюджетний кодекс України: Закон України від 08 липня 2010 року [Електро- нний ресурс]. - Режим доступу: // http://zakon1.rada.gov.ua/cgi-bin/laws/main.

2. Порядок покриття тимчасових касових розривів місцевих бюджетів: Затв. постановою Кабінету Міністрів України від 29.12.2010 р. №1204. [Електронний ресурс] - Режим доступу: http:// http://zakon4.rada.gov.ua/laws/show/12042010-\%DO\%BF/paran $10 \#$ n 10

3. Русін В._Переваги та недоліки казначейського обслуговування місцевих бюджетів. //Світ фінансів 2013.-вип. 4- с.110

4. Постанова Кабінету Міністрів України «Деякі питання ведення обліку податків і зборів (обов'язкових платежів) та інших доходів бюджету» від 16 лютого 2011 р. № 106

5. Закон України «Про Державний бюджет України» станом на 2015, № 5, с.37

6. Про Державне казначейство України: Указ Президента України від 27 квітня 1995 р. [Електронний ресурс] - Режим доступу: http://zakon.rada.gov.ua.

7. Постанова Кабінету Міністрів України «Питання Державного казначейства України» від 21 грудня 2005 року №1232. [Електронний ресурс] - Режим доступу: http://zakon4.rada.gov.ua/laws/show/1232-2005-п

Експерт редакційної колегії к.е.н., доцент УкрДУЗТ Сухорукова Т.Г.

УДК 336.27

\title{
РОЛЬ БАНКІВСЬКОГО КРЕДИТУВАННЯ У РОЗВИТКУ МАЛОГО БІЗНЕСУ В УКРАÏ̈I
}

Калініченко Л. Л., д.е.н., доцент,

Мусіяка К. В., махістр (УкрДУЗТ)

У статті нами було досліджено роль банківського кредитування малого бізнесу в Україні, його стан на данній період часу, та проблеми, з якими він стикається в своїй діяльності. Зазначено основні особливості кредитування малого підприємниитва комериійними банками Украйни. Вказано та проаналізовано основні проблеми, пов'язані з кредитуванням суб'єктів малого бізнесу, а також запропоновано підходи щодо удосконалення системи кредитування малих підприємств. портфель.

Ключові слова: малий бізнес, економіка, розвиток форм і методів кредитування, кредитний

\section{РОЛЬ БАНКОВСКОГО КРЕДИТОВАНИЯ В РАЗВИТИИ МАЛОГО БИЗНЕСА В УКРАИНЕ}

\author{
Калиниченко Л. Л., д. э н., доцент, \\ Мусияка Е. В., магистр (УкрГУЖД)
}

В статье исследованы особенности банковского кредитования малого бизнеса,состояние бизнеса в данный момент и проблемы, с которыми он сталкиваеться в совей деятельности. Указаны основные особенности кредитования малого предпринимательства комерческими банками Украины. Перечислены и проанализированны основные проблемы,связанные с кредитованием субьектов малого бизнеса, а также предложены подходы к усовершенствованию системы кредитования мальх предприятий.

Ключевые слова: малый бизнес, економика, развитие форм и методов кредитования, кредитный портфель.

(C) Калініченко Л.Л., Мусіяка К.В.
Вісник економіки транспорту і промисловості № 50, 2015 


\title{
THE CHARACTER OF BANK LENDING IN THE SMALL BUSINESS DEVELOPMENT IN UKRAINE
}

\author{
Kalinichenko L. L., dr. of e.s., \\ Musiyaka E., master (UU of R)
}

In the article research a specialty of bank lending to small businesses and study the characteristics of bank lending to small businesses. Study the characteristics of bank lending to small and medium businesses. Trends, advantages and disadvantages of loan products for small and medium businesses were analyzed. Indicate the main features of lending to small businesses. The possibility of cluster approach in bank lending was considered for the purposes of efficiency of small businesses. Listed in analyzing the main problems and subjects of small business lending, as well as the different forms of lending, based on integrated approach, were proposed for various activities of small businesses. The possibility of standardization combination in the form of loans was established that may increase the availability of loans for different groups of small businesses.

Keywords: small business, economy, development of forms and methods of credit, loan portfolio.

Постановка проблеми. Рушійною силою відновлення позитивних темпів економічного зростання $€$ підприємництво, функціонування якого не можливо без запозичення фінансових ресурсів. Однак у структурі кредитування банків малий бізнес займає лише близько $2 \%$ через низку причин, до яких вітчизняні фахівці відносять [1, c.74] низький рівень попиту на кредити 3 боку дрібних підприємців; невисоку рентабельність цього напряму кредитування для банків; недосконалість нормативно-правової бази; труднощі об'єктивної оцінки реального фінансового стану суб'єктів малого підприємництва, нестачу ліквідного забезпечення кредитів, високі ризики неповернення кредитів; брак довгострокових коштів у банківській системі; малоефективний механізм державних гарантій.

Як показує практика господарювання вітчизняних малих підприємств, за результативністю своєї діяльності вони ще не посіли належного місця, відповідно до світового рівня. В Україні частка малого бізнесу у ВВП становить лише $11 \%$, а кількість підприємств у розрахунку на 10 тис. осіб - 63 одиниці, тоді як у ринково розвинутих країнах цей показник становить 500-700 одиниць [3, с.315].

Ситуація у сфері малого i середнього бізнесу та гострота проблеми занадто дорогих кредитів для малих підприємців вимагає подальших досліджень у вищезазначеному напрямі. Головною проблемою вітчизняних малих підприємств $є$ нестача фінансових ресурсів для підтримки бізнесу та його подальшого розвитку. Одними із основних напрямів підтримки бізнесу $є$ фінансова допомога міжнародних та українських фінансових організацій та фондів, позики комерційних банків та кредитних спілок, лізинг. Але всі вищезазначені джерела не $є$ достатньо досконалими, тому обрана тема є актуальною.

Аналіз останніх джерел і публікацій. Проблема розвитку малого бізнесу є об'єктом для досліджень вже на протязі багатьох років, тому їй присвячена низка праць як вітчизняних, так i зарубіжних вчених. Зокрема слід відмітити таких науковців, як Варналій 3. С. [1], Герасимович А. М., Галь В. [2], Зверьков А.І. [3], Косова Т. Д. [4], Коцовська Р. Р. [5], Кривоног О. Л. [6], Лук'янченко В. О. [4], Муичев А. [7] та ін. Однак дуже багато питань щодо кредитування малого бізнесу носять дискусіний характер.

Метою статті є: визначення ролі банківського кредитування у розвитку малого бізнесу в Україні та розробка підходів щодо удосконалення системи кредитування малих підприємств.

Виклад основного матеріалу дослідження. У сучасних умовах пожвавлення підприємницької діяльності, особливо малого бізнесу, для його функціонування необхідні додаткові фінансові ресурси. Аналіз світового досвіду свідчить про те, що у загальних обсягах фінансування малих підприємств упродовж останніх сорока років переважають кредити [2, c.13]. В опитуванні, що проводили фахівці серед підприєців, називалися такі причини, що спонукали їх звернутися по кредит до певного банку: умови кредитування, а саме процентні ставки, термін кредиту (30\%); надійність банку (37\%); тривалий досвід на ринку кредитування малого бізнесу (13\%); оперативність прийняття рішення про надання кредиту (10\%); довірчі відносини з банком, особисті контакти (10\%) [5] (рис. 1).

Таким чином, очевидними є відмінності в поглядах представників малого бізнесу та банкірів на причини доступності кредитів. Для усунення цих відмінностей доцільно сконцентрувати спільні зусилля на розвитку форм і методів кредитування iз прийнятними характеристиками для малого та середнього бізнесу, що передбачає перехід до клієнтоорієнтованого підходу та налагоджування партнерських стосунків із підприємцями. 


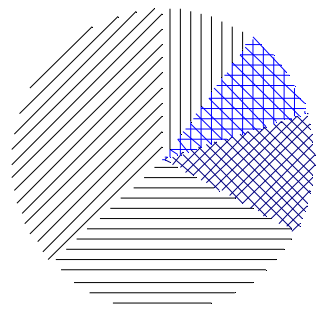

\author{
\%. Надійність банку,(37)\% \\ $=$ Процентна ставка, величина \\ комісії,(30)\% \\ * Тривалий досвідна ринку \\ кредитування,(13)\%
}

* Оперативність про прийняття рішення,(10)\%

Довірчі відносини з банком

Рис. 1. Причини вибору підприємцем певного банку

Отже, перспективи розвитку форм кредитування малого бізнесу пов'язані із двома дещо суперечливими, на перший погляд, підходами. Перший - підвищення доступності кредитів на основі стандартизації форм та спрощення процедур надання кредитів. Другий підхід - клієнтоорієнтований, спрямований на формування партнерських відносин із позичальником, посилення індивідуалізації та комплексності банківського обслуговування.

Обидва підходи до кредитування суб'єктів малого бізнесу мають переваги і недоліки, а тому банки повинні приділяти увагу кожному із них. Стандартизація форм кредитування здійснювалася на основі використання методів кредитного скорингу, комп'ютерних моделей оцінки кредитів, застосування лімітів за овердрафтом.
Ha практиці спрощення процедури кредитування i стандартизація характеристик кредитів призводить до скорочення їх асортименту та зниження доступності через жорсткіші умови кредитної угоди для зменшення кредитних ризиків. Тому такий підхід можна охарактеризувати як пасивний, що певною мірою знижує роль банківського кредитування як стимул активізації розвитку малого підприємництва.

Структура кредитного портфеля кредитних спілок України на 31 грудня 2013 року показує, що спілки надають споживчих кредитів $67 \%$ загального обсягу портфеля; кредити на навчання, лікування 8\%; на підприємницькі кредити припадає $25 \%$. (рис. 2) [5, с.153]

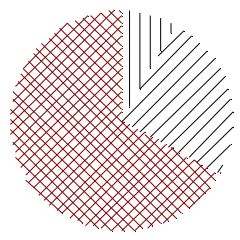

Споживчі кредити, 67\% || Інші кредити, 8\%

\%. Підприємницькі кредити, $25 \%$

Рис. 2. Структура кредитного портфеля кредитних спілок Украӥни станом на 31 грудня 2013 року

Малі підприємства залучають кредитні кошти за рахунок комерційних банків. На практиці взаємини українських банків і суб'єктів малого підприємництва носять, на перший погляд, парадоксальний характер. 3 одного боку, банки повинні бути зацікавлені в наданні кредитів суб'єктам малого бізнесу, оскільки одержують за це відсотки, але напроти, вони кредитують малі підприємства неохоче. 3 боку підприємств, вони мають велику потребу в кредитах, але не звертаються за ними в банк [6, с.102].

Незацікавленість банків у видачі кредитів суб'єктам малого підприємництва можна пояснити такими причинами:

1.Для банків робота 3 малими підприємствами не є ефективною. Розгляд великої кількості інвестиційних проектів при високій собівартості операцій по їх обробленню для банків є не рентабельною. Це пов'язано 3 відсутністю відпрацьованих технологій по інвестуванню малих підприємств.

2.Кредитування малого бізнесу пов'язано 3 великими ризиками для банків. Дана проблема $є$ основною причиною відмовлення банків від кредитування малого бізнесу. Проте, за статистикою малі підприємства є одними із самих дисциплінованих позичальників. Неповернення або прострочення кредиту складає лише $1-2 \%$ $[7, \mathrm{c} .25]$.

3.Для одержання кредиту суб'єктові малого підприємництва необхідно надати бізнес-план, вигідний інвестиційний проект. В свою чергу складання якісного бізнес-плану потребує звертання до кваліфікованих спеціалістів. Щоб уникнути цієї проблеми потрібно або навчити підприємців професійному бізнес-плануванню, або 
створити такі умови, за яких банк був би сам зацікавлений кредитувати та доводити до кінця вигідний проект.

4.Ще одна проблема кредитування малого бізнесу полягає в тому, що банки не здатні організувати кредитування як “потокову” послугу. Для кредитування великого числа малих підприємств необхідно удосконалити механізми їх кредитування.

3 іншого боку є проблеми, з якими стикаються малі підприємства при бажанні отримати кредит:

По-перше - це коротка кредитна історія або iii повна відсутність. Підприємство, що було створено декілька місяців або років назад має набагато менше шансів на одержання кредиту, ніж те підприємство, що давно діє на ринку, неодноразово брало кредити і його знають як клієнта.

По-друге, банки дають кредити підприємствам, що мають постійний стабільний оборот, який потрібно продемонструвати. Банкові потрібні гарні показники, а малі підприємства через непосильне оподаткування нерідко змушені приховувати свої доходи, у тому числі і від кредитних організацій.

По-третє, малі підприємства не можуть взяти кредити на довготривалий термін через досить невеликий термін власного існування, а використовуючи короткострокові кредити, вони не встигають здобути великі прибутки, які б дали можливість їм здійснювати розширене виробництво [4].

Не зважаючи на всі проблеми, малі підприємства продовжують боротьбу за виживання в складних умовах. Сьогодні в Україні значну роль у розв'язанні проблем кредитування малого бізнесу виконують кредитні лініі, започатковані міжнародними фінансовими організаціями та НБУ. На українському ринку кредитують малий i середній біщнес такі банки як Європейський банк реконструкції та розвитку, Світовий банк, Німецький банк реконструкції [6,с.103].Та привабливість таких кредитів для підприємців в умовах інфляції зменшується, так як позики надаються у вільно конвертованій валюті, а підприємець отримує прибуток у гривні.

Висновки. Як показує досвід, для ефективного функціонування сфери малого підприємництва необхідна підтримка 3 боку держави. В першу чергу необхідно вдосконалити законодавчі механізми кредитування малих підприємств. Для цього необхідно:

1. Змінити Закон України "Про державну підтримку малого підприємництва”. Він був прийнятий ще у 2000 році і звістно потребує вже змін, бо не повністю відповідає потребам малого підприємництва, яке значно зросло та змінилося.

2. Переглянути норми кредитування, що закріплені у Законі України "Про банки і банківську діяльність”, у відомчих актах НБУ і Міністерства фінансів. Тому що вони регулюють питання кредитування в цілому і не враховують специфіку малого бізнесу.

3. Розробити проект закону "Про кредитування суб'єктів малого підприємництва”, розглянути його та прийняти. В цьому законі повинні бути зазначені різні форми кредитування малого бізнесу, схеми надання i погашення кредитів.

Це надасть державі можливість здійснити реальну підтримку малого бізнесу і тим самим створити більший прошарк середнього класу.

Для успішного подальшого розвитку малого підприємництва в Україні потрібно і надалі розвивати та вдосконалювати системи фінансовокредитної підтримки малих підприємств. Для цього потрібно:

1. налогодити технології кредитування суб'єктів малого підприємництва банківськими структурами;

2. розробити механізм участі держави в розподілі ризиків при кредитуванні суб'єктів малого бізнесу;

3. удосконалити норми кредитування підприємств, з урахуванням специфіки та потреб малого підприємництва;

4. прийняти адекватну заставну законодавчу базу;

5. удосконалити нормативно-правовий механізм взаємодії небанківських фінансових організацій і малих підприємств 3 питань видачі позики малим підприємствам та індивідуальним підприємцям;

6. розробити підходи до організаційноекономічного механізму фінансової підтримки малого підприємництва в Україні.

\section{СПИСОК ЛІТЕРАТУРИ}

1. Варналій 3. С. Мікрокредитування малого підприємництва /3. С. Варналій, С. Г. Дрига, Л. Л. Тарангул. - Ірпінь: НУДПСУ, 2008. $144 \mathrm{c}$.

2. Галь В. Розвиток малого та средього бізнесу в Україні // Вісник НБУ. - 2003. - №1. - С. $12-15$.

3. Зверьков А. И. Малый бизнес: доступность кредитов и банковские инновации [Электронный ресурс]/А.И. Зверьков //Государственная программа финансовой поддержки малого и среднего бизнеса, 2011. Режим доступу:

http://www.mspbank.ru/ru/support_program/a nalytical materials

4. Косова Т. Д. Формування механізму фінансово-кредитної підтримки малого підприємництва / Т. Д.Косова, В. О. Лук'янченко //Фінанси України. - 2002. - №12. - С.37 - 41. 
5. Коцовська Р. Р. Кредитні спілки як альтернативні установи щодо кредитування малого підприємництва / Р. Р. Коцовська // Регіональна економіка. - 2014. - №3. - С. $149-155$.

6. Кривоног О. Л. Банківське кредитування малого підприємництва// Фінанси України. / . Л. Кривоног О- 2005. - №8. - С. $101-105$.

7. Мурычев А. Банки и малый бизнес / А. Мурычев //Бизнес Предложения. - 2010. - №5 - 6.
- C. $24-31$.

8. Статистичний щорічник України. - Київ: видавництво “Консультант”, 2011. - 575 с.

9. Народные критерии оценки банковского обслуживания [Электронный ресурс] //Национальное агенство финансовых исследований, 2.12.2011 Режим доступу:

http://nacfin.ru/novosti-i-

analitika/press/press/single/10516.html

Експерт редакційної колегії к.е.н., дочент УкрДУЗТ Зубенко В.О.

\title{
УДК 336.71
}

\section{ІДЕНТИФІКАЦІЯ ЗАГРОЗ ФІНАНСОВІЙ БЕЗПЕЦІ БАНКІВ}

\author{
Коковіхіна О.О. к.е.н., доцент, \\ Олійник А. Ю., ст. (УкрДУЗТ)
}

У статті проаналізовані існуючі підходи щзодо класифікації загроз фінансовій безпеці банку. Запропоновано авторську класифікаџію, яка на відміну від існуючих враховує таку класифікаџійну ознаку як «діяльність регіональних та структурних підрозділів банку», щео дозволить проводити своєчасні заходи, з приводу їх запобігання або мінімізації.

Ключові слова: фінансова безпека, загроза фінансовій безпеці, комерційний банк.

\section{ИДЕНТИФИКАЦИЯ УГРОЗ ФИНАНСОВОЙ БЕЗОПАСНОСТИ БАНКОВ}

\author{
Коковихиной $А$. А., к.э.н., доцент, \\ Олейник А.Ю., ст. (УкрГУЖТ)
}

В статье проанализированы существующие подходы к классификащии угроз финансовой безопасности банка. Предложено авторскую классификацию, которая в отличие от существующих учитывает такой классификационный признак как «деятельность региональных и структурных подразделений банка», что позволит проводить своевременные мероприятия по поводу их предотвращения или минимизации.

Ключевые слова: финансовая безопасность банка, угроза финансовой безопасности, коммерческий банк.

\section{IDENTIFYING THREATS TO THE FINANCIAL SECURITY OF BANKS}

\author{
Kokovikhinoj O.O.,Candidate of Economic Sciences, associate dotsent, \\ Oleinik A. Yu., studentyt (USU of RT)
}

The article analyzes the existing approaches to the classification of threats to the financial security of the Bank. Considerable attention is paid to the classification of financial security of the Bank and different views on it. The urgency of development of internal measures minimize security Bank, as the Bank has not only the main office, not even one branch,and nakaiana work in the security system may lead to the fact that the system will fail,and in our case the Bank. Then can affect not only the depositors but also the state in General. The author suggests a classification that unlike the existing account, for such classification criterion as "the activities of the regional and structural subdivisions of the Bank."

Keywords: financial security, a threat to the financial security of a commercial Bank.

Постановка проблеми. Оцінка кризових ситуацій у фінансовій сфері пов'язана 3 виявленням і аналізом реальних загроз фінансовій безпеці економіки в різних іï сегментах, зокрема і банківському. Деструктивні процеси у фінансових відносинах мають багатофакторний характер i пов'язані як функціонально, так і структурно 3 багатьма макро- і мікропроцесами розвитку, що 